УДК 373.04: 159. 922. 76-056.49

DOI: $10.35619 /$ iiu.v1i11.272

Ціпан Тетяна

кандидат педагогічних наук, доцент, доцент кафедри теорії і методики виховання Рівненського державного гуманітарного університету, м. Рівне, Україна ORCID: 0000-0002-1356-2825 e-mail:23ttss22@ukr.net

\title{
ПРЕВЕНЦІЯ АСОЦІАЛЬНОЇ ПОВЕДІНКИ НЕПОВНОЛІТНІХ: ПСИХОЛОГО-ПЕДАГОГІЧНА ДІАГНОСТИКА
}

\begin{abstract}
Анотація. У статті розкрито психолого-педагогічний аспект превенції асоціальної поведінки неповнолітніх. Проаналізовано поняття «превенція», «асоціальна поведінка». Схарактеризовано форми асоціальної поведінки: девіантна, адиктивна, суїцид. Встановлено, що превентивна діяльність є системним утворенням, що включає діагностичний, прогностичний, плануючий, регулюючий і контрольний етапи. Розкрито сутність діагностичного етапу. Запропонована низка діагностичних методик для виявлення причин виникнення асоціальної поведінки неповнолітніх.

3'ясовано, що превенція асоціальної поведінки у закладі освіти повинна починатися із з'ясування можливих причин відхилень у поведінці школярів, пов'язаних із порушенням дисципліни (грубість, невідвідування школи, лайка, вживання нецензурної лексики), тобто, з діагностики проблеми. Це, по-перше, дозволить зібрати і систематизувати інформацію, на підставі якої може бути зроблений той чи інший висновок, і по-друге, визначити мету і завдання, які необхідно вирішити для попередження у школярів відхилень у поведінці і надання їм педагогічної підтримки. 3 огляду на те, що первинна превенція полягає в комплексному впливі не тільки на школярів з асоціальною поведінкою, а й на їхнє найближче оточення (однокласників, батьків, педагогів), то на цьому етапі доцільна просвітницька діяльність, що включає проведення циклу тренінгових занять.
\end{abstract}

Педагогічна підтримка передбачає: надання неповнолітнім педагогічної допомоги у важких життєвих ситуаціях, формування в них стійкості до прояву різного роду протиправних дій і поведінки, сприяння їх захисту від негативних впливів, орієнтація на саморозвиток, самоствердження, самоорганізацію i самореалізацію неповнолітньіх та норми життя і діяльності в цивілізованому суспільстві.

Ключові слова: асоціальна поведінка, превенція, превентивна діяльність, неповнолітні, діагностика, діагностичні методики, тренінгові заняття, педагогічна підтримка.

Постановка проблеми. Глобальні світові процеси, соціально-економічна, політична нестабільність українського суспільства створюють об'єктивні передумови для дегуманізації підростаючого покоління, збільшення кількості неповнолітніх з асоціальною поведінкою. Асоціальна поведінка торкається усіх сфер соціального функціонування неповнолітніх і проявляється вербальною i фізичною агресивністю, негативним ставленням до оточення, нездатністю 
прогнозувати результати своєї поведінки, слабкою емоційною прихильністю до близьких, низьким рівнем сформованості комунікативних навичок тощо (Сжова та ін., 2014).

Провідну роль в організації превенції асоціальної поведінки відіграє школа як соціально-педагогічна система, яка поширює свій вплив на лише на всіх учасників освітньо-виховного процесу, але й на оточуючий соціум. Адже саме система освіти і виховання має зробити людину такою, щоб вона могла вирішувати державні завдання за своїм покликанням, бути високоморальною, духовно розвиненою, мобільною в своєму розвитку (Пєхота, 2002, с. 41). Тому одне 3 важливих завдань школи - попередити поведінкові відхилення неповнолітніх і порушення ними моральних і правових норм, сформувати у школярів стійкість до асоціальних проявів у суспільстві. Вирішенню цього завдання має сприяти превенція, тобто попередження негативних явищ у шкільному середовищі.

Аналіз останніх досліджень 3 проблеми. Питання профілактики неповноправної поведінки неповнолітніх розглядається в наукових доробках низки вітчизняних та зарубіжних вчених. Наприклад, проблема профілактики девіантної поведінки неповнолітніх розкрита у дослідженнях І. Козубовської, В. Татенка, В. Терещенко, Т. Федорченко; соціально-педагогічним причинам виникнення асоціальної поведінки неповнолітніх присвячені наукові роботи Є. Костяшкіна, В. Ковальова, А. Сманцера; психологічний аспект правопорушень серед неповнолітніх досліджували С. Бєлічева, В. Ковальов; технологія створення превентивного виховного середовища розкрита в наукових працях О. Сжової, С. Кириленко, В. Оржеховської, Т. Федорченко; шляхи і засоби попередження асоціальної поведінки учнів висвітлені в роботах В. Баженова, Л. Кондрашової. Вчені О. Пилипенко, В. Слюсаренко акцентували увагу на способах удосконалення педагогічної діяльності вчителя, класного керівника в організації превентивного виховання в закладах середньої освіти. Дані наукових досліджень Л. Дзюбко, Н. Онищенко, Г. Товканець, Б. Чередрецької доводять необхідність здійснення превенції негативних проявів у поведінці дітей шкільного віку.

Мета статті - розкрити сутність психолого-педагогічної діагностики у контексті превенції асоціальної поведінки неповнолітніх.

Виклад основного матеріалу дослідження. Превенція у перекладі з латинської (praeventio) означає випереджати, попереджати; 3 англійської (prevention) попередження, запобігання. У сучасній вітчизняній та зарубіжній психологопедагогічній літературі є чимало визначень поняття «превенція», що підтверджує важливість цієї проблеми.

Наприклад, А. Сманцер тлумачить це поняття як «загальне попередження, запобігання, випередження негативних дій і поведінки дітей, а також допомога i підтримка у складних ситуаціях» (Сманцер, 2008, с. 73-74).

На думку В. Оржеховської, превенція, як соціальна проблема, пов'язана із зміною моральної етики всього суспільства і вимагає об'єднання спільних зусиль різних соціальних інституцій (медичних, юридичних, педагогічних та психологічних) для позитивного вирішення цієї проблеми (Оржеховська, 2005, c.94).

У сучасній психолого-педагогічні науці вчені вирізняють соціальний, психологічний, правовий та педагогічний аспекти превенції.

Соціальний аспект превениії передбачає узгоджену і своєчасну реалізацію попереджувальних заходів, спрямованих на нейтралізацію причин, що викликають негативні прояви в поведінці школярів 3 метою поступового їх усунення (Оржеховська, 2005, с.94). 
Психологічний аспект пов'язаний з осмисленням психічної схильності дітей до неадекватної поведінки, виявлення дітей, схильних до порушення дисципліни та проявів асоціальної поведінки.

Правовий аспект розглядається у контексті дотримання школярем своїх прав, сумлінним виконанням обов'язків, формуванням правової культури.

У педагогічному аспекті превенція - це загальне попередження, запобігання, попередження, негативних дій і поведінки дітей, тобто асоціальної поведінки.

Асоиіальна поведінка - сукупність людських дій та вчинків, що суперечать існуючим у даному соціумі культурним нормам, соціальним правилам та обов'язкам

(http://esu.com.ua/search_articles.php?id=44466Асоціальна\%20\%20поведінка). Вона виражається в таких формах:

- девіантна поведінка - здійснення вчинків, які протирічать загальноприйнятим нормам соціальної поведінки (норми психічного здоров'я, права, культури чи моралі);

- адиктивна поведінка - порушення поведінки, що виникає в результаті зловживання різними речовинами, що змінюють психічний стан людини, включаючи алкоголь і тютюн, до того моменту, коли фіксується факт психічної i фізичної залежності, а також Інтернет-залежність. (https://www.google.com/search?q=адиктивна\%20\%20поведінкаһttps://ww w.google.com/search?q=адиктивна\%20\%20поведінка);

- суїцидна поведінка, пов'язана із бажанням здійснити самогубство.

Превенція - це категорія превентивної педагогіки. Тому розглянемо сутність діяльності класного керівника щодо превенції асоціальної поведінки школярів.

Діяльність - це «специфічно людська форма активного ставлення до навколишнього світу, зміст якої складає його доцільна зміна і перетворення» (Новая философская энциклопедия, 2000, с 633). Превентивна діяльність - це складова педагогічного процесу, заздалегідь спланована система виховних дій, спрямована на виявлення можливих відхилень дітей у поведінці за допомогою спеціально підібраних методик, оволодіння школярами накопиченого людством позитивного досвіду поведінки в суспільстві та засвоєння моральних норм і правил поведінки, попередження та усунення можливих порушень дисципліни.

Превентивна діяльність $є$ системним утворенням, яка складається 3 таких етапів: діагностичний, прогностичний, плануючий, регулюючий і контрольний (за Л. Кондрашовою). Аналізуючи алгоритм розпізнавання відхилень, А. Бєлкін вводить поняття «діагностична ситуація», під яким мається на увазі сукупність природно виникаючих або спеціально створених умов, що дають інформацію, придатну для діагностичних цілей. Отримана інформація дозволяе здійснити кількісний та якісний аналіз ситуацій, що виникають (Белкин, 1981, с. 17).

Оскільки головне завдання превенції асоціальної поведінки полягає у ранньому виявленні причин, які сприяють відхиленню від норм поведінки, то розкриємо сутність іï діагностичного етапу. Діагностику слід починати 3 аналізу психологічного клімату класного/шкільного колективу, характеру міжособистісних відносин в ньому у режимі «учень-учень», «учень-батьки», «учень-вчитель», «вчитель-батьки». Дослідження доводять, що для школярів, із відхиленнями у поведінці, характерна розмитість моральних орієнтацій. Вони спотворено розуміють суть таких моральних понять, як добро і зло, справедливість і честь, обов'язок і гідність, свобода і відповідальність. Тому ефективною в цьому плані буде методика «Що таке добре, а що погано» (автор I. Дерманова), призначена для діагностики сформованості моральних уявлень «Я». Опитувальник 
«Яка дитина у взаєминах з оточуючими людьми?» (автор Т. Бабаєва) допоможе вирізнити особливості дитячого колективу та особистісні якості його членів. Оцінюються комунікативні якості, вміння об'єктивно оцінювати інших людей, уміння ставитися до інших людей доброзичливо. За допомогою методики «Діагностика прийняття інших (за шкалою Фейя)» можна визначити уявлення підлітка про себе і оточуючих, ступінь прийняття ним індивідуальності оточуючих людей.

Важливим є виявлення мотивів поведінки школяра, його ставлення до навчання і праці, частота прояву відхилень у поведінці і причини їх виникнення, характер домагань і самооцінка неповнолітнього, схильності, природні задатки, улюблені заняття i захоплення, типове проведення вільного часу, наявність друзів i референтних осіб, позитивні і негативні риси особистості, рівень іiі вихованості тощо. Методика «Соціометрія» (автор Дж. Морено) буде ефективною для діагностики міжособистісних $\mathrm{i}$ міжгрупових відносин 3 метою їх зміни, покращення і вдосконалення. За допомогою соціометрії можна вивчати типологію соціальної поведінки людей в умовах групової діяльності, судити про соціально психологічну сумісність членів конкретних груп

Виявити слабкі та сильні сторони кожного члена класного/шкільного колективу i на основі цього розпізнати схильність школяра до порушення дисципліни допоможе діагностична методика «Крокодил». Вона допомагає знімати показники емоційного стану досліджуваного, діагностувати його інтелектуальний розвиток, а також сприяє виявленню у дітей агресивних тенденцій. Методика «Тест тривожності» (автори Р. Темл, М. Дорки, В. Амен) сприятиме виявленню тривожності стосовно низки типових для дитини життєвих ситуацій спілкування 3 іншими людьми. Тривожність розглядається як вид емоційного стану, функція якого полягає в забезпеченні безпеки суб'єкта на особистісному рівні.

Важливим є виявлення спрямованості особистості (громадська, індивідуальна, ділова або групова), визначення їі ціннісних орієнтацій, розуміння школярем сенсу життя і майбутні професійні наміри, виявлення ставлення до оточуючих його людей (однолітки, вчителі, батьки). Ефективною у цьому плані є методика Рокича «Ціннісні орієнтації».

Ефективним у превенції асоціальної поведінки $є$ також такий діагностичний інструментарій: «Діагностика рівня морально-етичної відповідальності особистості» (автор I. Тимощук), методика «Шкала емоційного відгуку» (автори А. Меграбян і Н. Енштейн), «Методика діагностики міжособистісних відносин» (автори Т. Лірі, Г. Лефоржем, Р. Сазек), методика діагностики загальної комунікативної толерантності (автор В. Бойко), експрес-опитувальник «Індекс толерантності» (автори Г. Солдатова, О. Кравцова, О. Хухлаєв, Л. Шайгеров), «Визначення стилю поведінки у конфліктній ситуації» (автор К. Томас), тест «Опис поведінки в конфлікті» (автор К. Томас), «Діагностика самооцінки та міри домагань» (автори Т. Дембо, С. Рубінштейн, адаптація А. Прихожан), «Визначення схильності до адиктивної, агресивної, деліквентної поведінки» (автор О. Орел) тощо.

Таким чином, за результатами аналізу та інтерпретації діагностичного матеріалу класний керівник отримує інформацію про реальний стан розвитку школяра та причини його поведінкових відхилень. Повнота і об'єктивність інформації при початковій діагностиці в максимальному ступені наближає планування виховних завдань до реальних потреб класу і відповідає оптимальному розвитку вихованців (Краснова, Харченко, Юрків та Сьомкіна, 2011, с.21). Діагностика дає можливість узагальнити інформацію про якість i рівень 
виконуваної класним керівником психолого-педагогічної роботи в класі, що в цілому слугує поштовхом для вироблення нової стратегії виховання, спрямованої на корекцію виховного процесу в класі.

Первинна превенція полягає у комплексному впливі не тільки на школярів 3 асоціальною поведінкою, а й на їхнє найближче оточення (однокласників, батьків, педагогів). На цьому етапі доцільна просвітницька діяльність, яка сприятиме ознайомленню школярів із стратегіями поведінки в загрозливих для життя ситуаціях, проведення циклу тренінгових занять.

Мета і завдання тренінгових занять у контексті превенції відхилень у поведінці:

- зниження ворожості, агресивності, зменшення емоційних реакцій, які призводять до агресивної поведінки;

- оптимізація міжособистісних відносин, підвищення групової згуртованості та налагодження сприятливого психологічного клімату як в окремо взятому класі, так і закладі освіти в цілому;

- превенція відхилень в емоційній сфері суб'єктів освітнього процесу, формування навичок володіння власними емоційними станами, зокрема адекватного й безпечного вираження гніву;

- підвищення рівня комунікативної культури, конфліктологічної компетентності учнів;

- розвиток стресостійких якостей у всіх суб'єктів освітнього процесу;

- розвиток здатності розуміти свої почуття, переживання, стан та інтереси інших дітей, позицію позитивного прийняття іншого;

- формування стратегій і навичок прийняття рішення і подолання складних життєвих ситуацій;

- формування навичок відстоювати свою територію i захищати свій персональний простір;

- формування навичок захищати своє «Я».

Тренінгові заняття передбачають діалогічний зв'язок між його суб'єктами. А діалог допомагає створити атмосферу взаєморозуміння, допомоги, захисту i взаємоповаги, обмежити негативні чинники впливу оточуючого середовища, посилюючи позитивне за рахунок підвищення значимості стійких мікосередовищ (Сжова та ін., 2014).

Висновки і перспективи подальших розвідок. Діяльність школи щодо превенції асоціальної поведінки повинна охоплювати всіх суб'єктів освітнього процесу - всі вікові категорії школярів, вчителів, батьків, адміністрацію і будуватися на основі системного підходу, який дозволяє інтегрувати i систематизувати накопичені знання, знаходити інваріанти психологічних описів, уникати недоліків локального підходу, підвищувати ефективність системних досліджень освітньо-виховного процесу.

Превенція асоціальної поведінки у закладі освіти повинна починатися із з'ясування можливих причин відхилень у поведінці школярів (порушення дисципліни, грубість, невідвідування школи, лайка, бійки, залякування, цькування, вживання нецензурної лексики), причин прилучення до наркотичних речовин (тютюн, алкоголь, наркотики тощо), тобто, з діагностики проблеми, що по-перше: дозволяє зібрати і систематизувати інформацію, на підставі якої може бути зроблений той чи інший висновок, і по-друге, визначити мету і завдання, які необхідно вирішити для попередження відхилень у поведінці. Основне завдання превенції асоціальної поведінки полягає у ранньому виявленні причин, які спричинюють відхилення у поведінці, у створенні умов, які забезпечать можливість їх нормального розвитку, тобто наданні педагогічної підтримки 
школяреві. Педагогічна підтримка вчителя, спрямована на превенцію асоціальної поведінки, включає: педагогічну допомогу неповнолітнім у важких життєвих ситуаціях, виховання у них стійкості до прояву різного роду протиправних дій i поведінки, сприяння їх захисту від негативних впливів, орієнтація на саморозвиток, самоствердження, самоорганізацію і самореалізацію неповнолітнього та норми життя і діяльності в цивілізованому суспільстві.

Перспективи подальших розвідок вбачаємо у розробці психокорекційних i профілактичних програм, спрямованих на попередження проявів асоціальної поведінки неповнолітніх, в яких діагностиці відводиться значне місце.

\section{СПИСОК ВИКОРИСТАНИХ ДЖЕРЕЛ}

Єжова, О. О. та ін. (2014). Формування превентивного виховного середовища загальноосвітнього навчального закладу : навч.-метод. посіб. /за заг. ред. д.П.н., проф. Оржеховської В. М. Кіровоград : Імекс ЛТД, 172 с. http://lib.iitta.gov.ua/7864/1/FORMUVANNIa\%20PREVENTYVNOHO\%20VYKhOV NOHO\%20SEREDOVYShchA\%20ZNZ.pdf. [Дата звернення 02.05.20p.]

Пєхота, О.М. та ін. (2002). Освітні технології : Навч. - метод. посіб. / За заг. ред. О. М. Пехоти. Київ: А. С. К. 255 с.

Сманцер, А. П., Рангелова, Е.М. (2008). Превентивная педагогика: методология, теория, методика. Минск : БГУ, 263 с.

Оржеховська, В. М. (2005). Соціально-педагогічні проблеми девіантної поведінки неповнолітніх у сучасних умовах. Педагогіка і психологія. №4, с. 90-98.

http://esu.com.ua/search_articles.php?id=44466. Асоціальна поведінка [Дата звернення 04.05.20p.]

https://www.google.com/search?q=адиктивна\%20\%20поведінка; [Дата звернення 04.05.20p.]

Новая философская энциклопедия: в 4 т. М., 2000. Т. 1, с. 633.

Белкин, А. С. Теория и методика педагогической диагностики отклонений в поведении школьников. Доктор педагогических наук. Москва, 1981, с. 17.

Краснова, Н.П., Харченко, Л.П., Юрків, Я.І., Сьомкіна І.С. (2011). Сочіальнопедагогічна діагностика: наук.-метод. посіб. для студ. вищ. навч. закл. держ. закл. «Луган. нац. ун-т імені Тараса Шевченка». Луганськ: Вид-во ДЗ «ЛНУ імені Тараса Шевченка», 2011, 429 с.

\section{REFERENCES}

Yezhova, O. O. ta in. (2014). Formuvannia preventyvnoho vykhovnoho seredovyshcha zahalnoosvitnoho navchalnoho zakladu [Formation of a Preventive Educational Environment of a General Educational Institution]: navch.-metod. posib. /za zah. red. d.p.n., prof. Orzhekhovskoi V. M. Kirovohrad : Imeks LTD, 172 s. http://lib.iitta.gov.ua/7864/1/FORMUVANNIa\%20PREVENTYVNOHO\%20VYKhOVNO HO\%20SEREDOVYShchA\%20ZNZ.pdf. [Data zvernennia 02/05/20 r.] (in Ukrainian)

Piekhota, O.M. ta in. (2002). Osvitni tekhnolohii [Educational Technologies]: Navch.--metod. posib. / Za zah. red. O. M. Piekhoty. Kyiv: A. S. K. 255 s. (in Ukrainian)

Smantser, A. P. \& Rangelova, E. M. (2008). Preventivnaya pedagogika: metodologiya, teoriya, metodika [Preventive Pedagogy: Methodology, Theory, Methods]. Minsk: BGU, 2008. 263 s. 263 s. (in Russian)

Orzhekhovska, V. M. (2005). Sotsialno-pedahohichni problemy deviantnoi povedinky nepovnolitnikh u suchasnykh umovakh [Socio-pedagogical Issues of Deviant Behavior of Minors in Modern Conditions]. Pedahohika i psykholohiia. No4 S. 90-98. (in Ukrainian) 
http://esu.com.ua/search_articles.php?id=44466. Asotsialna povedinka [Data zvernennia 04/05/20 r.]

https://www.google.com/search?q=adyktyvna\%20\%20povedinka; [Data zvernennia 04/05/20 r.]

Novaia fylosofskaia эntsyklopedyia: v 4 t. Moskva, 2000. T. 1. S. 633.

Belkyn, A. S. Teoryia y metodyka pedahohycheskoi dyahnostyky otklonenyi v povedenyy shkolnykov [Theory and Methods of Pedagogical Diagnosis of Deviations in the Behavior of Schoolchildren]. Doktor pedahohycheskykh nauk. Moskva, 1981. S. 17. (in Ukrainian)

Krasnova, N.P., Kharchenko, L.P., Yurkiv, Ya.I., Somkina I.S. (2011). Sotsialnopedahohichna diahnostyka [Socio-pedagogical Diagnostics:]: nauk.-metod. posib. dlia stud. vyshch. navch. zakl. derzh. zakl. "Luhan. nats. un-t imeni Tarasa Shevchenka". Luhansk: Vyd-vo DZ "LNU imeni Tarasa Shevchenka”, 2011. 429 s. (in Ukrainian)

\title{
PREVENTION OF ASSOCIAL BEHAVIOR OF MINORS: PSYCHOLOGICAL AND PEDAGOGICAL DIAGNOSTICS
}

\author{
Tetiana Tsipan \\ Candidate of Pedagogical Sciences, \\ Associate Professor, Associate Professor at the Department of \\ Theory and Methods of Education, \\ Rivne State University for the Humanities, \\ Rivne, Ukraine \\ ORCID: 0000-0002-1356-2825 \\ e-mail:23ttss22@ukr.net
}

\begin{abstract}
The article deals with the issue of asocial behavior of minors. The concepts of "prevention", "asocial behavior" were analyzed. Such forms of asocial behavior like deviant, additive, suicide were characterized. It was stated that preventive activity is a systemic formation, which consists of diagnostic, prognostic, planning, regulatory and control stages.

The essence of the diagnostic stage was revealed. A number of diagnostic techniques for identifying the causes of antisocial behavior of minors were proposed.

It was found that the prevention of asocial behavior in the educational institution should begin with identifying possible causes of deviations in the behavior of students, including violation of discipline (rudeness, non-attendance of school, swearing, use of obscene language), that with the diagnostic of the problem. Firstly, it will make it possible you to collect and systematize the information on the basis of which a conclusion can be made, secondly, to determine the goals and objectives that must be solved to prevent schoolchildren from deviating in behavior and providing them with pedagogical support.

Considering that primary prevention is a complex impact not only on students with antisocial behavior, but also on their immediate environment (classmates, parents, teachers), then at this stage it is advisable educational activities, including a series of training sessions. Pedagogical support includes: providing pedagogical assistance to minors in difficult life situations, bringing up of their resistance to the manifestation of various kinds of illegal actions and behavior, promoting their protection from negative influences, focus on self-development, self-affirmation, self-organization and selfrealization of a minor and norms of life and activity in a civilized society.
\end{abstract}

Keywords: antisocial behavior, prevention, preventive activity, minors, diagnostics, diagnostic methods, training sessions, pedagogical support.

Стаття надійшла до редакиії 07. 05. 2020 p. 